\title{
Investigation of Effects of Fumigation on Performance and Emission in Dual Fuel Engines Injection-Controlled With Electronic Card
}

\author{
Hüseyin Gürbüz ${ }^{1}$, and Tarkan Sandalcı ${ }^{1}$ \\ ${ }^{1}$ Automotive Division, Mechanical Engineering Faculty \\ Y1ldı Technical University, 34349 Istanbul \\ Turkey
}

\begin{abstract}
In order to contribute positively to the environmental and human health sensitivity, it is necessary to fight to reduce emissions of the diesel-induced pollutant. Ethanol is providing the notable potential to reduce particulate emissions in diesel engines since ethanol has lower carbon content than diesel fuel and it is oxygenated. In the present study, the effects of ethanol fumigation on engine performance and combustion characteristics and pollution emissions were investigated experimentally at eleven different engine speed in a turbocharged three-cylinder tractor diesel engine. The injector placed for spraying on the intake manifold was controlled by the ECU board developed as Arduino-based and the engine was driven with dual fuel. It was detected that cylinder gas pressure increased at the beginning of the combustion process and decreased during the last phase of combustion. The experimental results of the engine performance indicated for the ethanol fuel are higher than that of diesel fuel. HC emissions have declined considerably, and NOx emissions have decreased compared to diesel fuel at high speed.
\end{abstract}

Key Words: Tractor, Diesel engine, Ethanol Fumigation, Arduino cart, pollution emissions

\section{INTRODUCTION}

The most important factors that threaten human and nature health are fossil fueled internal combustion engines which are increasingly increasing in number. Several studies have been carried out to allow engines to perform low emission emissions. Liquid fuels as alternative fuels, which are used in petroleum-based engines, in accordance with their existing structures and operating principles and which can be used with little or no modification on existing engines during transition period from conventional motors to electric motors, are considered to be more advantageous. Therefore alcohols are to keep important place in a renewable alternative liquid fuels. In recent years, it has been declared by the World Health Organization International Agency for Research on Cancer (IARC) that air pollution is originated by some particulate matters [1]. When diesel is used, NOx emission and particulate matter occur [2]. However, alcohol fuels are cleaner than conventional fuels such as diesel and produce less THC and NOx emissions [3]. In addition, emissions have a significant impact on climate change as they show greenhouse gases. Worldwide greenhouse gas emissions from the agricultural sector are about 24\% [4].

As an alternative liquid fuel, ethanol $\left(\mathrm{C}_{2} \mathrm{H}_{5} \mathrm{OH}\right)$ can be an important fuel used to reduce pollutant emissions thanks to the oxygen contained in its content [5-6]. Emulsifiers and co-solvents can be used in blends to prevent phase separation of ethanol and diesel. But when emulsifier use in the blends, usually requires heating and blending steps [7]. However, the fumigation method is advantageous because it does not require an external mixer.

Rakopoulos et al.[8] reported increasing the ethanol amount in the fuel blend increased the brake specific fuel consumption in a turbocharged diesel engine fueled with ethanol fuel with 5\% and 10\%. Quadaris et al. [9] studied the effects of ethanol fumigation and ethanol-Diesel fuel blends on the performance and emissions of diesel engine have been researched. They found that by using $20 \%$ ethanol by fumigation method, soot mass concentration also decreased by $51 \%$, while an increase by $55 \%$ in $\mathrm{CO}$ emission, and by $36 \%$ in $\mathrm{HC}$ emissions. Also they detected that by using $15 \%$ ethanol by ethanol-diesel blend method, soot mass concentration also decreased by $32 \%$, while an increase by $43.3 \%$ in CO emission, and by $34 \%$ in $\mathrm{HC}$ emissions. Huang et al. [10] investigated the effects of blends of ethanol with diesel in a diesel engine. They reported that $\mathrm{CO}$ was found to be reduced at 
partial loads but were increase at high speed, HC emissions were rise at high speed and partial load. Tutak et al. [11] investigated effects of ethanol-diesel-biodiesel blends direct injection engine. The results show that THC and NOx emissions increased up to $\% 35$ percentage ethanol in the blend. Koganti et al. [12] evaluated the performance of 5\% ethanol-diesel blend in tractors with respect to fuel economy and emissions. A noticeable reduction in carbon monoxide (CO) and soot particulate matter was observed compared to diesel. However there was a slight increase in oxides of nitrogen (NOX). Kaulani et al. [13] reported a reduction in NOx emissions by $24 \%$ and $43 \%$ in their experiments using fumigation with $5 \%$ and $10 \%$ ethanol. Ghadikolaeia et al. [14] used fumigation and emulsion methods in their study. There was an increase in the release of NOx and HC by the emulsion method. In fumigation experiments, there was an increase in heat release and ignition delay compared with diesel fuel. The main objective of this article is to contribute to the clean air quality by reducing the pollutant emissions from agricultural tractors. The second fuel system is built without changing the current fuel system of the engine. Fumigation method was used in the second fuel system by injecting ethanol into the intake manifold port with the gasoline injector and the effects on exhaust emissions have been investigated. The injector was controlled by an integrated card with the arduino.

\section{EXPERIMENT METHODOLOGY}

In the present work, the effect of using diesel and ethanol with fumigation method on the performance and emission characteristics of a small tractor engine was investigated. The experiments were first run with only diesel fuel to determine the characteristics of the tractor engine. The motor was operated between $1100 \mathrm{rpm}$ and $2200 \mathrm{rpm}$ at partial loads. In this study, together with diesel fuel (E0) sprayed directly into the cylinder, agricultural production ethanol with $99.9 \%$ purity was sprayed into the intake manifold port at a rate of $10 \%$ (EF10) by volume for fumigation method. The reason for using $99.9 \%$ anhydrous ethanol in the experiments, $99.9 \%$ purity ethanol provides a better mixture more than $99.5 \%$ pure ethanol with diesel [15]. The properties of ethanol and diesel are shown in Table 1[16, 17].

Table1. Typical properties of diesel and ethanol

\begin{tabular}{|l|c|c|c|}
\hline Molecular formula & Unit & Diesel & Ethanol \\
Cetane number & - & $40-50$ & $\sim 8-9$ \\
Molecular weight & $\mathrm{g}$ & 205.2 & 46 \\
Liquid density & $\mathrm{kgm}^{-3}$ & 840 & 789 \\
Lower heating value & $\mathrm{MJkg}^{-1}$ & 42.5 & $\mathrm{C}_{2} \mathrm{H}_{5} \mathrm{OH}$ \\
Heat of evaporation & $\mathrm{kJkg}^{-1}$ & 260 & 840 \\
Auto-ignition temperature & $\mathrm{K}$ & 503 & 698 \\
Stoichiometric air-fuel ratio & - & 14.6 & 9.0 \\
Viscosity at 25 ${ }^{\circ} \mathbf{C}$ & $\mathrm{mPa}^{-\mathrm{s}}$ & 2.8 & 1.07 \\
Carbon content & $\%$ & 87 & 52.2 \\
Hydrogen content & $\%$ & 13 & 13.0 \\
Oxygen content & $\%$ & 0 & 34.8 \\
\hline
\end{tabular}

Before the experiments the test engine was run for 15 minutes to achieve the stable operating conditions. Hence, the tractor engine was operated with dual fuel. For the fumigation method, a gasoline injector placed on the engine's intake manifold was controlled by the Arduino-based ECU electronic card. The exhaust emissions were measured with AVL Dicom 4000 and AVL 415S gas analyzer, the in-cylinder pressure was measured with the AVL GH14P piezoelectric pressure sensor and Kistler 5011B as charge amplifier, the motor power was detected using S type Load cell. While the engine speed was measured with a Proximity sensor, the exhaust gas temperature was measured using a K-type thermocouple that was specifically positioned in the exhaust manifold. 
The schematic of the entire fuel system of the experimental apparatus is shown in Fig.1. Specification of Experiment engine can be seen in Table 2 .

Table 2. Test Engine Specification

\begin{tabular}{|l|c|}
\hline \multicolumn{1}{|c|}{ Parameters } & Specifications \\
\hline Cylinder Number & 3 \\
Aspiration & Turbocharge \\
Bore x Stroke & 104 x $115 \mathrm{~mm}$ \\
Compression Ratio & $18: 1$ \\
Cooling System & Water Cooled \\
Maximum Output & $36 \mathrm{~kW}$ \\
Rated Speed & $2450 \mathrm{rpm}$ \\
\hline
\end{tabular}

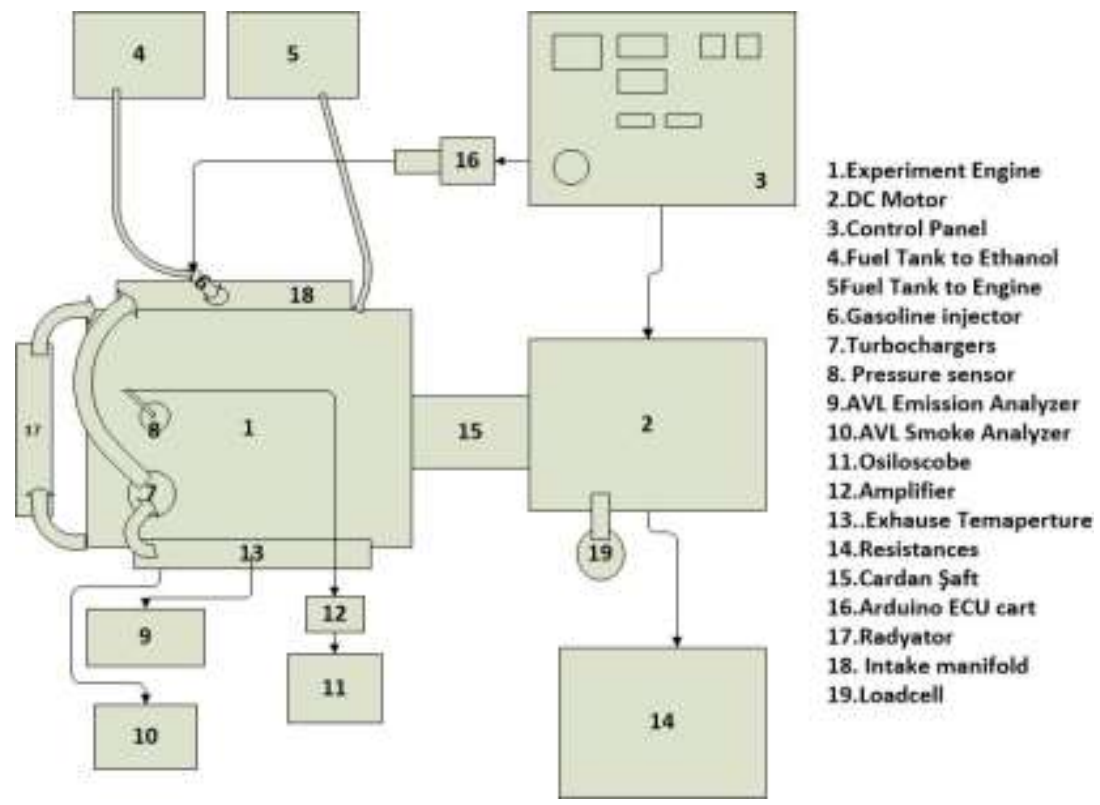

Fig.1. Schematic of the entire experimental system

\section{RESULTS AND DISCUSSIONS}

The use of ethanol with a $10 \%$ ratio for fumigation method in the graphs was shown as EF10, while the use of only neat diesel was represented as E0. The variation of the engine brake power obtained with firstly diesel (E0) and then the change of power with $10 \%$ ethanol fumigation (EF10) at various engine speeds is shown in Figure 2. As ethanol fumigation increases by $10 \%$, the engine power increases by $8 \%$. While operating below $1600 \mathrm{rpm}$ engine speed which is max torque, engine brake torque increased to $9.08 \%$ with EF10 in Fig. 3. These increases can be explained in that: although the total fuel cetane number of the fuel added to the combustion has been reduced with ethanol, with the increase in internal cylinder temperature due to the precombustion of ethanol, which provides a good mixture with turbocharged compressed air before the injection of diesel fuel, can be related to better combustion of diesel fuel. The maximum power was provide at $1600 \mathrm{rpm}$ while the maximum torque was supply at $2000 \mathrm{rpm}$. 


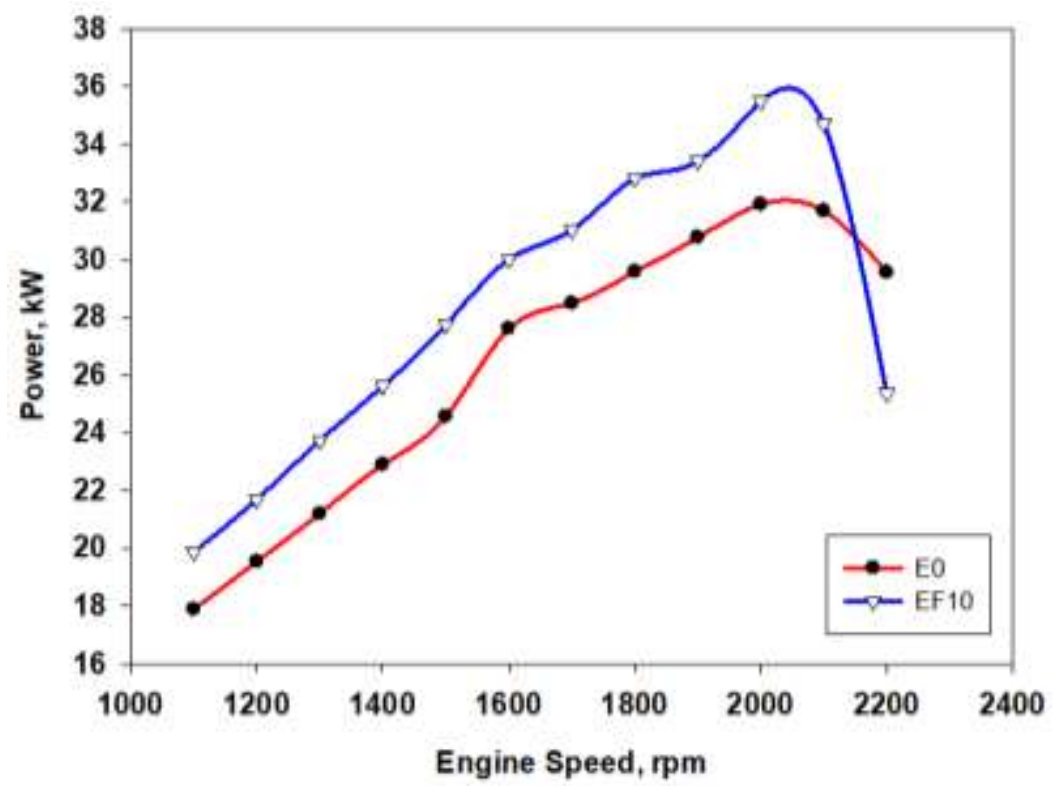

Fig. 2. Engine power output versus engine speed using ethanol-diesel fumigation at different speeds.

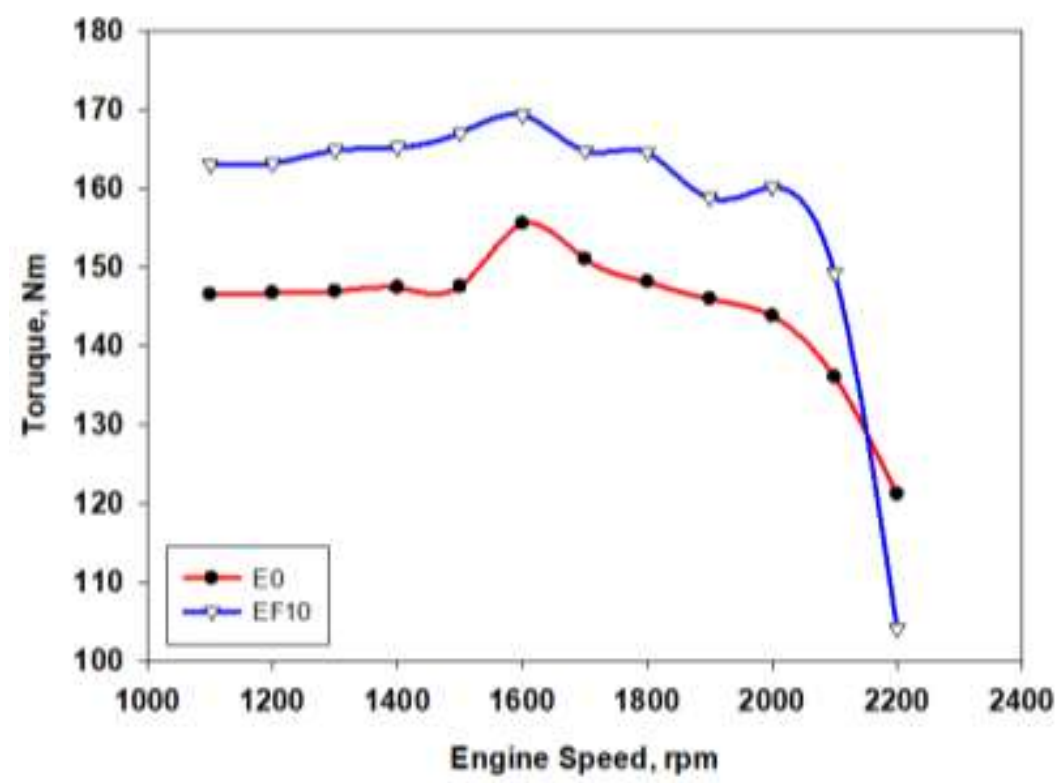

Fig. 3. Engine brake torque output versus engine speed using ethanol-diesel emulsion at different speeds

HC emission decreases by $79.8 \%$ with EF10 in Fig. 4. HC emissions of the blends are lower than that of diesel because complete combustion will be full burning owing to oxygen inside ethanol. While the tractor engine is running at medium speeds, it has been determined that the metallic noise can be heard and the operating characteristic is unstable. However, the metallic sound, which can be heard by ethanol fumigation, has decreased considerably. This can be seen with the reduction of HC emissions. 


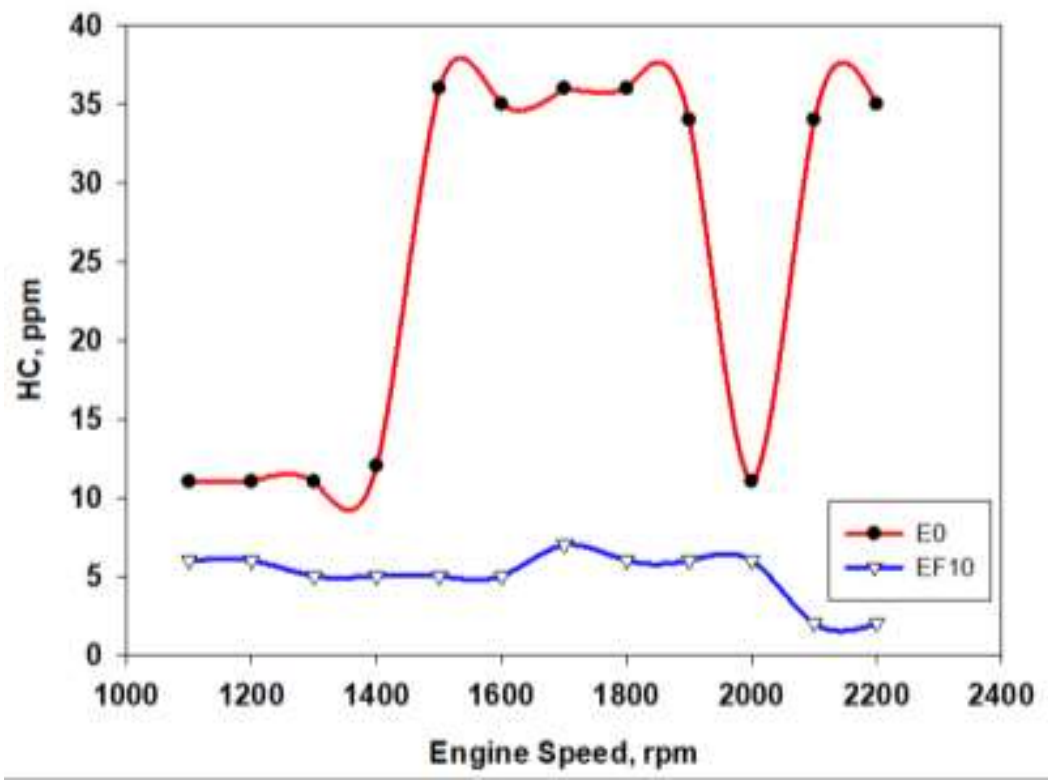

Fig. 4. THC emissions versus engine speed using ethanol-diesel emulsion at different speeds.

The variation of the Nitrogen oxide emissions with different engine speed is shown in Fig. 5. The low cetane ethanol number causes prolongation of the ignition delay. Thus ethanol can homogenize the mixture with air. Combustion of ethanol vapor, which provides a good mixture with turbocharged air, can ensure better combustion of the main fuel diesel. Therefore, it may lead to an increase in NOx emissions due to temperature increase in the cylinder.

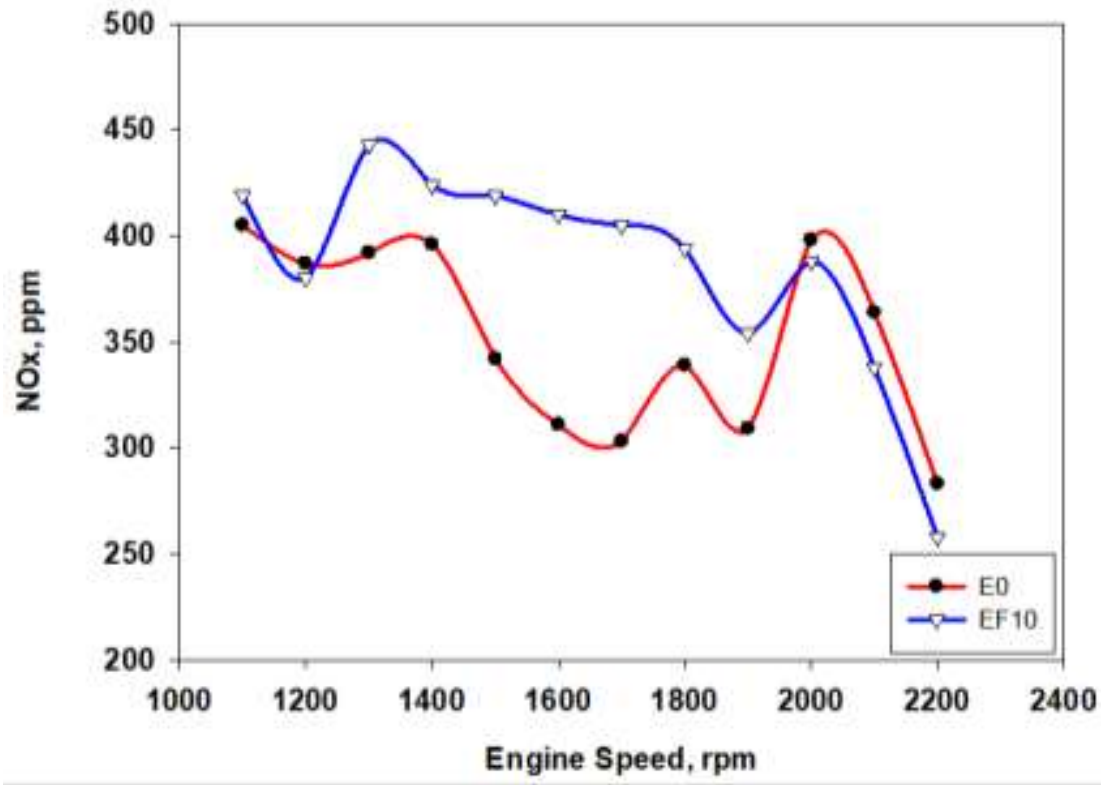

Fig. 5. NOx emissions versus engine speed using ethanol-diesel emulsion at different speeds

Variation of the soot concentration at different engine speeds is shown in Fig. 6. There was a decrease \%13 as conclusion of study in smoke emissions but there was a slight increase in the medium engine speeds. The most important reason for this is that the engine has started to knock due to unstable operation characteristics of engine at medium speeds. 


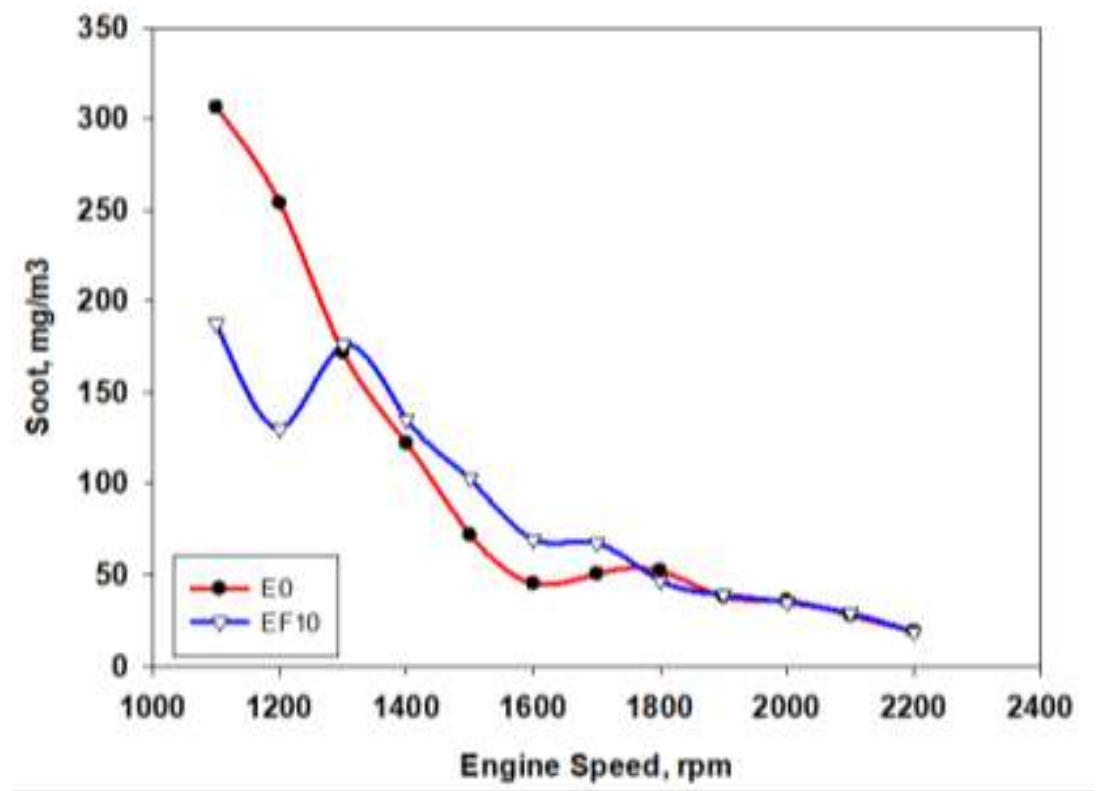

Fig. 6. Variation of Soot density versus using ethanol-diesel emulsion at different speeds

The combustion parameters such as the change of cylinder gas pressure and heat release rate are discussed with reference to the crank angle. The experiments were conducted at maximum torque speed (1600 rpm) and maximum power speed (2000 rpm) for E0 and EF10 fuels. The in-cylinder pressure, heat release rate and mass fraction burned for neat diesel and EF10 fuels are compared in the following Fig. 7 and Fig. 8. The maximum combustion pressure increases as the engine load rising because of the increase in the amount of fuel injection. The peak cylinder pressure happen at almost the same crank angle for all fuels. As it can be seen from the two pressures graph, cylinder pressures with ethanol fumigation take higher values than diesel fuel. In addition, ethanol fumigation has been shown to start earlier and more energy is released in the vicinity of Top Dead Center (TDC.)

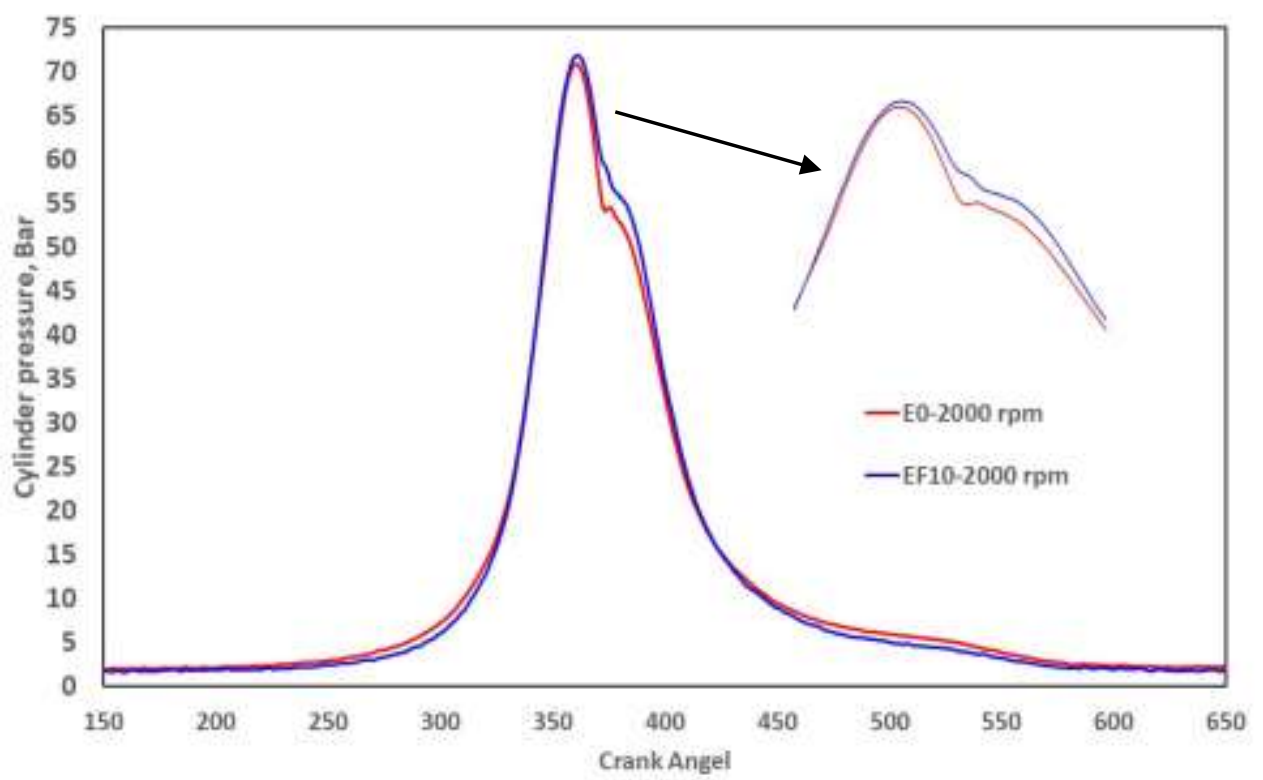

Fig. 7. Variation of cylinder pressure with crank angle for $2000 \mathrm{rpm}$. 


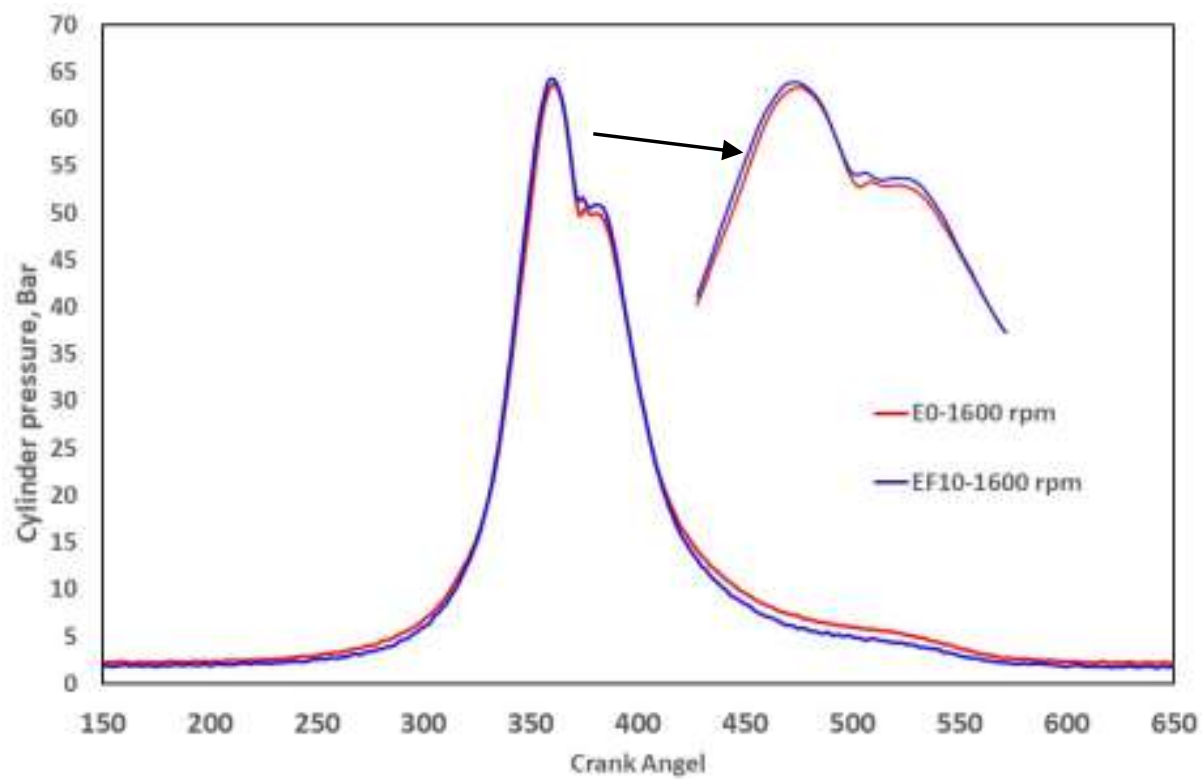

Fig. 8. Variation of cylinder pressure with crank angle for $1600 \mathrm{rpm}$.

Increased peak pressure with ethanol fumigation can be caused by ethanol vapor which provides a good mixture with the compressed air taken during the suction stroke, burning before the diesel burn. Ignition and combustion duration of E0 and EF10 fuels can be seen with the increase of ethanol, ignition delay and combustion duration shrink. With Ethanol fumigation, TDC vicinity pressure may be caused by the prolonged ignition delay time and by the sudden burning of ethanol + fuel vapor around the accumulated fuel in this time. It can also be foreseen that the fuels taken during ignition delay will increase engine power [18].

\section{CONCLUSION}

The main results obtained can be summarized as follows:

- In the tractor engine, there is an improvement in the cylinder pressure with ethanol fumigation.

- In the use of $10 \%$ ethanol, engine power, torque and pollutant emissions have improved. However, NOx was slightly increased at medium speeds. In this respect, the fumigation method for this tractor, which works under field load, was found to be quite favorable.

- HC emissions were significantly reduced with ethanol fumigation.

- Smoke emission has been decreased at low speeds but is similar to diesel combustion at high speeds.

- The ethanol blends which made in certain conditions, can be used directly in any agricultural tractor.

\section{REFERENCES}

1. Subramanian, K. A., "A comparison of water-diesel emulsion and timed injection of water into the intake manifold of a diesel engine for simultaneous control of NO and smoke emissions," Energy Conversion and Management, 52(2): pp. 849-857, 2011

2. Baghdadi S. M. A. R., " Performance study of a four-stroke spark ignition engine working with both of hydrogen and ethyl alcohol as supplementary fuel maher," International Journals of Hydrogen Energy, 25, pp. 1005-1009, 2000

3. Climate Change 2014 Synthesis Report Summary for Policymakers, IPCC ,2014

4. Niven R. K., "Ethanol in gasoline: environmental impacts and sustainability review article". Renewable and Sustainable Energy Reviews, 9(6), pp.535-555., 2005.

5. Masood Y. M., "Effect of ignition timing and compression ratio on the performance of a hydrogen-ethanol fueled engine" International Journal of Hydrogen Energy, pp.6945-6950, 2009

6. Yahuza I, Dandakouta H. "A performance review of ethanol-diesel blended fuel samples in compression-ignition engine", Journal Chemical Engineering Process Technology, 6: 256, 2015

7. Rakopoulos D.C., Kakaras E.C., Giakoumis E., "Effect of ethanol-diesel fuel blends on the engine performance and emissions of heavy duty DI diesel engine," Energy Conversion and Management, 49(11), pp. 3155-62, 2008

8. Qudais M.A., Haddad O., Qudaisat M., "The effect of alcohol fumigation on diesel engine performance and emissions", Energy Conversion and Management, 41 (11), 389-399, 2000 
9. Huang, J. Wanga, Y. S. Li, A.P. Roskilly, H. Yu, H. Li," Experimental investigation on the performance and emissions of a diesel engine fuelled with ethanol- diesel blends," Applied Thermal Engineering, 29, pp. 2484-2490, 2009

10. Tutak W.,.A "Comparative study of co-combustion process of diesel-ethanol and biodiesel-ethanol blends in the direct injection diesel engine", Applied Thermal Engineering, 117,pp. 155-163, 2017)

11. Koganti R.B., Maheshwari M., Swami K.K, Malhotra R.K, Arora P., Singh V.P., Varyani F.S. "Performance evaluation of ethanol diesel blend in Tractors." SAE, Paper no.2004 28-0085: pp. 544-550,2004

12. S. A. Kaulani1, Z. A. Latiff1, M. R. M. Perang, M. F. M. Said, and M. F. Hasan, "Performance and emission of compression ignition (CI) engine using ethanol-diesel blending as a fuel" , Proceedings Of The 3rd International Conference On Automotive Innovation Green Energy Vehicle: Aigev , 2018 .

13. Meisam Ahmadi Ghadikolaeia, Chun Shun Cheunga Ka-FuYungb, "Study of combustion, performance and emissions of a diesel engine fueled with ternary fuel in blended and fumigation modes" Fuel, 235, pp. 288-300, 2019

14. Shahir S.A., Masjuki H.H., Kalam M.A., Imran A., Rizwanul Fattah I.M, ve Sanjid A. "Feasibility of diesel-biodieselethanol/bioethanol blend as existing CI engine fuel: An assessment of properties, material compatibility, safety and combustion", Renewable and Sustainable Energy Reviews, 32: pp. 379-395, 2014

15. Zhu L., Cheung C.S., Zhang W.G., Huang Z., "Combustion, performance and emission characteristics of a di diesel engine fueled with ethanol-biodiesel blends," Fuel, 90(5): pp. 1743-1750, 2011

16. Tutak W., Jamrozik A., Pyrc M., Sobiepański M, "Investigation on combustion process and emissions characteristic in direct injection diesel engine powered by wet ethanol using blend model ", Fuel Processing Technology, 149, pp. 86-95, 2016

17. Şahin, Z., Durgun, O. "Theoretical investigation of effects of light fuel fumigation on Diesel engine performance and emissions", Energy Conversion and Management, 48, pp.1952-1964 , 2007 